Journal of Applied Finance \& Banking, Vol. 11, No. 3, 2021, 81-110

ISSN: $1792-6580$ (print version), 1792-6599 (online)

https://doi.org/10.47260/jafb/1134

Scientific Press International Limited

\title{
Impact of Specialization, Ownership Structure, and Size on Cost and Profit Efficiency of US Commercial and Savings Banks
}

\author{
Md. Asif Nawaz ${ }^{1}$
}

\begin{abstract}
Using an unbalanced panel dataset of 5,265 observations from 454 US banks including 394 commercial and 60 savings banks, and Battese and Coelli (1995) Stochastic Frontier model, this study has determined the recent level of cost and profit efficiency estimates of these banks and analysed the impact of specialization, ownership structure, and size on the cost and profit efficiency. The results reveal that the cost efficiency of US commercial and savings banks is statistically higher than the profit efficiency with a score of $92.1 \%$ and $63.59 \%$ respectively; the global financial crisis did not affect cost efficiency much, but it had a shattering effect on the profit efficiency; the savings banks are more cost efficient than the commercial banks and commercial banks are more profit efficient than savings banks; there is no significant differences between the cost and profit efficiencies of privately and publicly owned banks; foreign banks are less cost and profit efficient compare to their domestic counterparts; and finally, the small banks enjoy higher cost and profit efficiency than their large, medium, and very large counterparts. The other determinants of cost and profit efficiency were found to be expectedly affecting the cost and profit efficiency of US banks.
\end{abstract}

JEL classification numbers: C33, C67, D22, D24, G01, G21, G32.

Keywords: Cost Efficiency, Profit Efficiency, US Commercial and Savings Banks, Bank Specialization, Ownership Structure, Bank Size.

1 Assistant Professor, Department of banking and Insurance, University of Dhaka, Bangladesh.

Article Info: Received: February 1, 2021. Revised: February 24, 2021.

Published online: March 25, 2021. 


\section{Introduction}

The efficiency and stability of the banking sector are considered as the barometer of the financial sector and macroeconomic stability of a country because the modern banking sector has grown to such a level where we can hardly think of any activity without banks. The offering of the transaction account, working as a source of liquidity, and acting as the major channel of monetary policy transmission, differentiate banks from any other types of organization (Corrigan, 1982). Most importantly, banks form the major part of the payment system of an economy, play the vital role of financial intermediation, and mobilize the required business capital (Hughes and Mester, 2013). According to Schumpeter (1934), the banking sector is the backbone of economic development and the prime source of capital for longterm investments. However, all these positive impacts can only come with the efficient and effective performance of the banking sector. Levine (1998) stated that a country's economic growth, to a great extent, depends on the level of efficiency of the financial intermediation and the failure of the banks has a severe impact on the economy. For example, the damages done to the global economy by the Global Financial Crisis (GFC) of 2007-2009. It is now well-known fact that the highly risky and inefficient banking activities were among the main catalysts of the crisis.

The GFC steered many banks to close down their several domestic and overseas businesses which immensely impacted the performance of the banking industry. Alongside, around the world a lot of structural changes in the banking sector have been observed especially development in technology, changes in regulations, and changes in the nature of banking activities. These changes have also influenced banks' ways of doing business and ultimately their level of efficiency of producing services by minimising costs and increasing profits. United States of America (USA) is no exception to these ongoing changes. In the past few decades, the USA has experienced a lot of significant changes in its banking sector especially due to the GFC. The collapse of the financial markets and the consequential economic downturn forced the regulators and policymakers of the country to bring some very important micro and macro-prudential regulatory changes. As a result of these changes, there has been a noticeable impact on the efficiency, productivity, and profitability of the US banks.

Considering all these reasons, research related to bank performance analysis has always been and still are at the focal point of operational research and financial economics. More precisely, modelling and evaluating bank performance, exploring the impacts of various regulations and policy measures on bank performance, finding the causes of technical, economic and allocative inefficiencies of banks and suggesting the ways for improved managerial performance and efficient resource allocation are the main topics of interest of this noble endeavour (Bhatia, et al. 2018). In the past decades, the performance analyses especially the efficiency analysis of the US banking sector has mostly attracted the researchers. The survey of the literature on efficiency analysis of the financial institutions included in Berger and Humphrey (1997) and Bhatia et al. (2018) testifies that a number of works on 
different aspects of bank and other financial institutions' efficiency have already been done. Among the studies, some have focused on the technical aspects of measuring efficiency (e.g. time-invariant and time-varying efficiency), some others have focused on the approaches of efficiency analysis (parametric and nonparametric approaches). Some studies have focused on determining efficiency levels and recommending policy implications from the observed facts while some others have explored the determinants of the differing efficiency levels among organizations.

However, this study aims to focus on several aspects of the efficiency analysis with the help of Stochastic Frontier Analysis (SFA). The major objective of this study is to estimate the cost and profit efficiency levels of the different categories (specialisation, private ownership, foreign ownership and bank size) of US commercial and savings banks before, during and after the period of GFC. This will also show the most recent average estimates of cost and profit efficiency levels of these categories of banks. Additionally, this study also examines if the concerned banks in the USA, on average, are more profit efficient or more cost efficient. Finally, it analyses the impact of Specialization, Corporate Governance, Ownership Structure, and Size on the cost and profit efficiency of the concerned banks taking into account the other bank-specific, industry- specific, and macroeconomic control variables.

The most important contribution of this study is that, in a single study, it is simultaneously analysing the impact of Specialization, Corporate Governance, Ownership Structure, and Size on cost and profit efficiency of the US commercial and savings banks, while most of the studies have focused on only one area for example size and bank efficiency (e.g. Akhigbe and McNulty, 2005) or ownership and bank efficiency (e.g. Altunbas, et al. 2001). In addition to that, the time frame (before, during, and after GFC) considered in this study is also important which will provide the stakeholders (policy makers, bank managers and regulators) most recent information and will help them to take effective and forward-looking decisions, implement strategies, and formulate policies. Finally, the study uses onestep Stochastic Frontier Analysis (Battese and Coelli 1995 model) to analyse the factors influencing cost and profit efficiency whereas, the studies, for this kind of analysis, use non-parametric (DEA) approach or other types of SFA models (including TFA, FDH, and Kumbhakar 1992 model). The advantage of using singlestep SFA have been highlighted in the subsequent sections.

\section{Literature Review}

The literature on the efficiency of banks in the USA is about half a century old and very rich. Elyasiani and Mehdian (1990a, 1990b) measured the cost efficiency of US banks using Data Envelopment Analysis (DEA) and Stochastic Frontier Analysis (SFA) and found 90\%, 88\%, 89\% and 96\% annual average cost efficiency levels for the studies period. Berger et al. (1993) using Distribution Free Approach (DFA) measured both cost and profit efficiency of US banks and found an average 
score of 52\% and 65\% respectively, and whereas, Berger and Mester (1997) and Bauer et al. (1993) analysed the cost efficiency of US banks using SFA, DFA, and Thick Frontier Approach (TFA) and found 67\%-90\% average efficiency levels. Barr et al. (1994) using DEA found $81 \%$ and $83 \%$ cost efficiency for US banks. Again, Adams et al. (1995) have found 61\%-77\% cost efficiency levels when Miller and Noulas (1996) found the US banks were only 3\% inefficient. Similar to the statement of Berger and Humphrey (1997), all these studies are indicating a mean $20 \%$ inefficiency of the banks in the USA till the year 2000.

Fan and Shaffer (2004) found that large US commercial banks were substantially inefficient, and the reasons were lower revenues rather than excessive costs. AlSharkas et al. (2007) studied US banking industry mergers and acquisitions and found merging increases efficiency and larger banks get closer to the efficient frontier. However, there is a shortage of literature on US banking efficiency after the GFC as recent studies focused more on fast-growing economies like China. Most recently, Tsionas et al. (2018) studied market power and efficiency with some internally consistent approach and found that US banks are on average $82.30 \%$ cost efficient. On the other hand, Ding and Sickles (2018), analysing the relationship between efficiency, capital structure, and portfolio risk, found that US banks were on average around 62\% efficient during the period 2001-2016. Restrepo-Tobón and Kumbhakar (2017) analysed the profit efficiency of US commercial banks using the data from 2001 to 2010 and various models and found varying profit efficiency levels for small, medium, and large banks. The results show an efficiency level between 70\%-96\% for the US banks. Nevertheless, this discussion summarizes that the efficiency level of US banks has increased since the 1990s maybe because of the technological advances and development of financial markets. This leads us to the discussion of the literature on the factors determining the efficiency in banks. While the studies in the 1990s on bank efficiency were more focused on the level of efficiency, the studies in 2000s are more focused on analysing the sources of these efficiencies. The analysis of the literature on efficiency determinants set the motion of this study and the choice of the variables. To mention, Vennet (2002) found that the source of differences in efficiency is the size and diversification by analysing the universal banks and conglomerates in Europe. Other studies (e.g. Weill, 2003; Mesa, et al. 2014; Delis, et al. 2009; Banya and Biekpe, 2017; Dell'Atti, et al. 2015; Havrylchyk, 2005; Tecles and Tabak, 2010; Ariff and Can, 2008; Das and Ghosh, 2009; Muazaroh, et al. 2012) analysing determinants of efficiency in countries other than USA found that size positively influences efficiency of the banks. The reasons of such results found by these studies include the economies of scale, product diversification and greater reach to customers. However, some studies on US banks (e.g. Akhigbe and McNulty, 2005) found that smaller banks are more efficient than their larger counterparts.

Another stream of studies (e.g. Weill, 2003; Yildirim and Philippatos, 2007; Fang, et al. 2011; Fries and Taci, 2005; Kasman and Yildirim, 2006; Kosak, et al. 2009; Gardener, et al. 2011; Kirkpatrick, et al. 2008; Das and Ghosh, 2009) looked into the ownership structure of the banks and its relationship with the efficiency and 
analysed the performances and efficiency of state- owned, domestic and foreign banks in various countries and tried to find the differences in their efficiency levels. The results are mixed; some found that foreign banks are more efficient than the domestic banks because of their better informational advantages, global reach, technology, and size; some other (e.g. Rouissi, 2011) found that domestic banks are more efficient than the foreign banks and government-owned banks because of the better understanding of the needs of the domestic market.

Besides, there are studies (e.g. Mesa, et al. 2014; Kosak, et al. 2009; Akhigbe and McNulty, 2005) looking into the effect of market structure and concentration on bank efficiency and found that concentration has a positive impact on efficiency through earning more revenue and making more loans, while competition increases efficiency as a means of survival for the fittest and through reducing costs. Moreover, there are studies which focused specifically on the bank-specific variables as the determinants of the bank efficiency (e.g. Ariff and Can, 2008 and Havrylchyk, 2005). The level of capital also influences bank efficiency through lower funding costs as the better-capitalised banks can borrow funds at a lower cost from the market (Kirkpatrick, et al. 2008; Havrylchyk, 2005) and according to Ariff and Can (2008), bank efficiency is influenced by the level of capital risk and liquidity risk. Also, the non-interest income and off-balance sheet exposure as the indicators of non-traditional activities of the banks affects the level of efficiency (Lozano-Vivas and Pasiouras, 2010; Rogers, 1998).

Furthermore, various studies found a significant impact of deregulation (Kirkpatrick, et al. 2008), regulations (Pasiouras, et al. 2009) on bank efficiency and almost all the studies have used the macroeconomic factors like economic growth, interest rate, inflation and unemployment as environmental variables determining bank efficiency. The higher economic growth and the lower interest rates create more investment opportunities and increase demand for bank loans thus influences the efficiency of the banks while the unemployment rates lower the cost of labour and positively influences bank efficiency.

The investigation of the existing literature on the bank efficiency analysis on US banks reveals some interesting gaps in the literature. Firstly, the literature on profit efficiency, especially on the USA is very thin. Secondly, there are very few studies focusing on efficiency analysis of US banks involving such a wider period including the years before, during and after the Global Financial Crisis. Thirdly, very few papers discuss the importance of profit efficiency over the cost efficiency of different categories of banks. Fourthly, the amount of studies involving parametric approach, especially one-step SFA, is very few as most of the studies are utilizing non-parametric Data Envelopment Analysis (DEA). Many empirical analyses on efficiency determinants follow a 'two-step' procedure ${ }^{3}$ which suffers from various

${ }^{3}$ In this approach efficiency scores are estimated first without considering the efficiency effecting determinants and then separately regressed against those determinants (Wang and Schmidt, 2002). 
econometric problems ${ }^{4}$ (Wang and Schmidt, 2002). Finally, as mentioned earlier, no study is simultaneously analysing the effects of Specialization, Ownership Structure, and Size on both cost and profit efficiency of US commercial and savings banks. Our study will fill up these gaps in the literature.

\section{Methodology, Variables and the Data}

Considering the advantages of one-step SFA models, this study uses Battese and Coelli (1995) model as it, in one single step, simultaneously estimates the levels of efficiency and analyse the effects of inefficiency determinants. The usual stochastic cost and alternative profit frontier models found in the literature are as follows:

And,

$\ln T C_{i t}=f\left(y_{i t}, p_{i t} \beta\right)+\varepsilon_{i t}$

$\varepsilon_{i t}=v_{i t}+u_{i t}$

$\ln \pi_{i t}=f\left(y_{i t}, p_{i t} \beta\right)+\varepsilon_{i t}$

$\varepsilon_{i t}=v_{i t}-u_{i t,} \quad i=1,2, \ldots \ldots N ; t=1,2, \ldots . T$

Where, $y_{i t}, \mathrm{TC}_{\mathrm{it}}$, and pit are vector of outputs, the total cost, and the vector of input prices respectively of $i_{\text {th }}$ bank at time $t$. The total cost is the sum of three inputs, labour, interest expenses, and other operating expenses. $\pi$ it is profit before taxes of bank $i$ at time $t$ and $\beta$ is the vector of parameters to be estimated. The vit is stochastic error term assumed to be normally distributed with a zero mean and constant variance. The inefficiency error term, $\mathrm{u}_{\mathrm{it}}$, is time- varying and takes only nonnegative values and it follows truncated (at zero) normal distribution. Again, the mean values $\mathrm{m}_{\mathrm{it}}$, of the inefficiency error term, are influenced by various determinants which can be defined as follows:

${ }^{4}$ Wang and Schmidt (2002) states that because of the model misspecification at the first step, the 'two-step' procedure provides biased results. They, using extensive Monte Carlo simulations, found a very substantial amount of biasness in the efficiency estimates following a 'two-step' procedure and argued strongly against it. Further, they proved that the 'two-step' procedure or ignoring the dependence of inefficiency on its determinants, estimates fake firm-level efficiency. Finally, they supported the use of models (like Battese and Coelli, 1995) which has efficiency determinantsconditional 'scaling properties' and that incorporates one-sided technical inefficiency error term which should be some function of inefficiency determinants and follows independent distributions. 

$m_{i t}=\partial_{0}+\partial z_{i t}+w_{i t}$
(1) for cost efficiency
$m_{i t}=\delta_{0}+\delta z_{i t}+w_{i t}$
(2) for profit efficiency

Where, $\mathrm{z}_{\mathrm{it}}$, is the vector of observable factors influencing cost and profit inefficiency of the banks and $\partial$ and $\delta$, are the coefficients to be estimated to measure the degree and direction of the influence of the considered variables. Since the profit efficiency concept examines both cost and revenue efficiencies (Isik and Hassan, 2002) and it is superior to cost efficiency methods, this study is also focusing on the profit efficiency of the US banks so that a thorough picture about the efficiency of the banking sector can be presented. Following Berger and Mester (1997) and DeYoung and Hasan (1998) 'alternative profit efficiency', which utilises the same output quantities and inputs prices as the cost frontier. There are several reasons for choosing 'alternative profit frontier': firstly, the standard profit efficiency uses output prices rather than output quantities and output prices are affected by severe measurement problems (Berger and Mester, 1997). Secondly, alternative profit efficiency is more appropriate and provide additional information when homogeneous output quality, competitive markets for outputs, efficiently measured output prices, and easily- changed output quantities, conditions of standard profit efficiency cannot be met (Berger and Mester, 1997; DeYoung and Hasan, 1998).

\subsection{Estimation of Efficiency}

Battese and Coelli (1995) model utilises the maximum likelihood method to estimate the coefficients of the variables used in efficiency frontier and in estimating the conditional means of cost and profit inefficiency $E\left(u_{i t} / \varepsilon_{i \mathrm{t}}\right)$. The Battese and Coelli (1988) option of estimating technical efficiency, which utilises mean of the distribution of $E\left[\exp \left(-u_{i t}\right) / \varepsilon_{i t}\right]$, is chosen over the Jondrow et al. (1982), JLMS, because the $\mathrm{BC}$ estimator is dominant in the efficiency literature. $E\left(u_{i \mathrm{t}} / \varepsilon_{i \mathrm{t}}\right)$ is an unbiased measure of $u_{i}$ however, it is inconsistent because of having non-zero estimator variance (Carvallo and Kasman, 2005). In estimating the cost and profit frontier, the study applies the usual Battese and Corra (1977) parameterization by replacing $\sigma^{2}$ and $\sigma^{2}$ with $\sigma^{2}=\sigma^{2}+\sigma^{2}$ and $\gamma=\sigma^{2} /\left(\sigma^{2}+\sigma^{2}\right)$. The gamma $(\gamma)$ indicates the inefficiency from the total noise and it ranges between zero and one. The value equal to zero implies that the deviation from the frontier is only due to only randomness and no way due to inefficiency and running an OLS is sufficient. On the other hand, the value equal to one indicates the presence of pure technical inefficiency. A cost efficiency value of 0.80 means the firm is $80 \%$ cost efficient and still using $20 \%$ more costs than the minimum level of costs required to produce the same level of outputs. On the other hand, for profit efficiency, a score of 0.80 means the firm is achieving $80 \%$ of the maximum possible profit in terms of the used inputs and produced outputs. and is still $20 \%$ profit inefficient. 


\subsection{Bank Production Theory and Selected Inputs and Outputs}

The efficiency analysis was started with analysing the efficiency of manufacturing firms. However, in 1990s researchers started using the frontier-based efficiency analysis for financial institutions especially for banks even though the choice of approach to select the inputs and outputs is still a matter of dispute. Some researchers (e.g. Pasiouras, et al. 2009) considered value-added or production approach $^{5}$ and most of the others (e.g. Yildrim and Philippatos, 2007; Ferrier and Lovell, 1990; Fries and Taci, 2005) used intermediation approach ${ }^{6}$.

The production approach, developed by Benston (1965), assumes that banks' main line of business is providing services to customers by processing transactions. On the other hand, the intermediation approach developed by Sealey and Lindley (1977), considers the banking activities like the act of transferring or intermediating funds between who have it (savers) and who want it (users). More precisely, as Laeven (1999) indicates that banks collect deposits and transform them into some earning assets like loans, investments, and other kinds of earning assets. Berger et al. (1987) argued that the intermediation approach should be preferred over production approach while choosing the inputs and outputs as the intermediation approach considers both operating and interest expenses and deposits as inputs.

There is still no clear-cut answer to which approach is more appropriate and the researchers improvise their definition of banking activities to choose inputs and outputs. In this study, the intermediation approach is followed. Therefore, the three output variables are total loans $\left(\mathrm{y}_{1}\right)$, other earning assets $\left(\mathrm{y}_{2}\right)$ (to capture the contribution of traditional banking activities in efficiency) and off-balance sheet items $\left(\mathrm{y}_{3}\right)$ (to capture the contribution of non-traditional activities to efficiency as in Lozano-Vivas and Pasiouras, 2010; Rogers, 1998; Clark and Siems, 2002). The prices of input variables are the price of labour (calculated as staff expenses divided by total assets) price of deposits (calculated as interest expense divided by deposits) and the price of physical capital (measured as ratio of operating expenses to fixed assets).

\footnotetext{
${ }^{5}$ Mathews and Zhang (2010) suggests that the production approach is appropriate for branch level efficiency analysis as it excludes interest expenses and considers only the operating costs. Finally, the outputs in the production approach are measured by the type and amount of processed transactions at a certain tenure and the lack of database for this actually testifies why researchers do not use this method quite often (Webb, 2003).

6 The main argument in using intermediation approach lies with the deposits being used as input. The deposits are considered as input by some researcher on the ground that they incur cost and do not produce any revenue unless they are turned into loans and other earning assets or investments. In that case, banks which do not depend on deposits rather on purchased liabilities, will deem more efficient (Berger et al. 1991). However, the approach suffered from the fact that it only uses onbalance sheet items which can be overcome by using the non-traditional outputs into the efficiency analysis (e.g. Rogers, 1998).
} 


\subsection{Preferred Functional Form of the Frontier}

To apply the parametric approach of estimating efficiency, the choice of the functional form to estimate the frontiers is also a crucial decision to be made. The Cobb-Douglas, the Quadratic, the Linear, the Normalised Quadratic, the Generalised Leontief, the Constant Elasticity of Substitution, the Transcendental Logarithmic (Translog) are the commonly used functional forms (Coelli, et al. 2005), however, Cobb-Douglas and Translog are the most competing ones in the literature. Coelli and Parelman (1999) states that Cobb-Douglas function, even though flexible and easy to calculate, does not allow to impose homogeneity restrictions. The Translog functional form proposed by J. Kmenta (1967) is dominating in the frontier analysis literature (Fried et al. 2008) because of its various advantages. It is very flexible, linear in parameters and it can be estimated using least squares methods (Coelli, et al. 2003). Furthermore, it is possible to impose required restrictions (homogeneity conditions) on the parameters in the Translog functional form. Therefore, this study is using the Translog functional form. However, we should be careful about the fact that the increased number of included parameters can increase the chance of multicollinearity and lead us to endup with a biased estimation of efficiency (Coelli, et al. 2005).

\subsection{Model Specification}

Based on the selected inputs and outputs, decided functional form, and the chosen parametric SFA approach of efficiency analysis the following cost and profit models can be specified:

$$
\begin{aligned}
\operatorname{lnT} C_{i t}=\alpha_{0}+ & \sum_{i=1}^{3} \alpha_{i} \ln y_{i t}+\sum_{j=1}^{3} \beta_{j} \ln p_{j t} \\
& +\frac{1}{2} \sum_{i}^{3} \sum_{k}^{3} \sigma_{i k} \ln _{i t} \ln y_{k t}+\frac{1}{2} \sum_{j}^{3} \sum_{\mathrm{h}}^{3} \gamma_{j \mathrm{~h}} \ln p_{j t} \ln p_{h t} \\
& +\sum_{i}^{3} \sum_{j}^{3} \delta_{i j} \operatorname{lny}_{i t} \operatorname{lnp}_{j t}+r_{1} \mathrm{t}+r_{2}(\mathrm{t} * \mathrm{t})+d_{1} \text { lnequityit } \\
& \left.+d_{2} \frac{1}{2} \text { (lnequity } * \text { lnequity }\right)+v_{i t}+u_{i t}
\end{aligned}
$$




$$
\begin{aligned}
\ln \pi_{i t}=\alpha_{0}+\sum_{i=1}^{3} & \alpha_{i} \ln y_{i t}+\sum_{j=1}^{3} \beta_{j} \ln p_{j t} \\
& +\frac{1}{2} \sum_{i}^{3} \sum_{k}^{3} \sigma_{i k} \ln y_{i t} \ln y_{k t}+\frac{1}{2} \sum_{j}^{3} \sum_{\mathrm{h}}^{3} \gamma_{j \mathrm{~h}} \ln p_{j t} \ln p_{h t} \\
& +\sum_{i}^{3} \sum_{j}^{3} \delta_{i j} \ln y_{i t} \ln p_{j t}+r_{1} \mathrm{t}+r_{2}(\mathrm{t} * \mathrm{t})+d_{1} \text { Inequity } \\
& \left.+d_{2} \frac{1}{2} \text { (lnequity } * \text { lnequity }\right)+v_{i t}-u_{i t}
\end{aligned}
$$

For linear homogeneity, following constraints with the symmetry being, $\gamma_{j, h}=$ $\gamma_{h, j} ; \delta_{i, j}=\delta_{j, i}$ is usually maintained:

$$
\sum_{j}^{3} \beta_{j}=1, \sum_{j}^{3} \gamma_{j, h},=0, \sum_{j}^{3} \delta_{i, j}=0
$$

Following Berger and Mester (1997), the model uses 'equity' and 'time' as the control variables to account for the homogeneity among the banks and to capture the effects of technical changes respectively throughout the studied period.

\subsection{The Determinants of Cost and Profit Efficiency}

At the final focal point of the study, is the analysis of Specialization, Corporate Governance, Ownership Structure, and Size and other controlled efficiency influencing factors and we must include them in the first stage of estimating efficiency because if we do not incorporate these variables into our analysis then the estimated efficiency will be biased (Wang and Schmidt, 2002). As mentioned earlier, Battese and Coelli (1995) model allows us to analyse the effects of determinants of cost and profit efficiency in the single step, this study is also focusing on some specific determinants, including the controlled ones, of cost and profit inefficiencies. Following equations (1) and (2), the models for both cost and profit inefficiency influencing determinants are as follows:

\section{For Cost Efficiency}

$m_{i t}=\partial_{0}+\partial_{1}$ Commercial Banks $s_{i}+\partial_{2}$ Unlisted Banks $_{i}+\partial_{3}$ Domestic Banks $_{i}+\partial_{4}$ $\operatorname{lnTA}_{i t}+\partial_{5}$ Liquidity $_{i t}+\partial_{6}$ Expense Management $_{i t}+\partial_{7}$ Assets Quality $_{i t}+\partial_{8}$ Capitalization $_{i t}+\partial_{9}$ Market Concentration $_{t}+\partial_{10}$ Economic Growth $_{t}+\partial_{11}$ Unemployment $_{t}+\partial_{12}$ Inflation $_{t}+\partial_{13}$ Money Supply $_{t}+\partial_{14}$ Interest Rate $_{t}+w_{i t}$ 
For Profit Efficiency

$m_{i t}=\delta_{0}+\delta_{1}$ Commercial Banks $_{i}+\delta_{2}$ Unlisted Banks $i+\delta_{3}$ Domestic Banks $i+\delta_{4}$ $\operatorname{lnTA}_{i t}+\delta_{5}$ Liquidity $_{i t}+\delta_{6}$ Expense Management $_{i t}+\delta_{7}$ Assets Quality $_{i t}+\delta_{8}$ Capitalization $_{i t}+\delta_{9}$ Market Concentration $_{t}+\delta_{10}$ Economic Growth $_{t}+\delta_{11}$ Unemployment $_{t}+\delta_{12}$ Inflation $_{t}+\delta_{13}$ Money Supply $_{t}+\delta_{14}$ Interest Rate $_{t}+w_{i t}$

\subsection{Required Data and their Main Sources}

The study is using an extensive dataset for the period 2003-2018. From the currently operating banks in USA, a total of 454 banks, including 394 commercial and 60 savings banks, have been selected for the study as they share the common characteristics and perform similar banking activities (Manghetti, 2011). These banks are selected on the basis of availability of their financial information for the period of 2003-2018 on the Orbis Bank Focus database. Therefore, the main source of bank-specific information is Orbis Bank Focus Database. The industry-specific information is calculated for required variables utilising the information from the Orbis Bank Focus Database. Finally, for the macro-economic variables, World Bank, International Monetary Fund, and Federal Reserve System's databases have been utilized where deemed necessary.

Table 1 presents the summary statistics of the data and variables used in this analysis. The observations in monetary values, are in billion dollars and deflated by the GDP deflators with a base year of 2003 to make it more comparable during the time period considered. The ratios are in percentage. Overall the data shows a good consistency with few extreme values. 
Table 1: Summary Statistics

\begin{tabular}{|c|c|c|c|c|c|}
\hline & Variables & Mean & Std. Dev. & Min & Max \\
\hline \multirow{3}{*}{ Outputs } & Total Loans $y_{1}$ & 13.43426 & 66.22926 & 0.00007 & 900.30360 \\
\hline & Other Earning Assets $y_{2}$ & 8.01044 & 55.85502 & 0.00115 & 977.96120 \\
\hline & Off-Balance Sheet Items $y_{3}$ & 25.68296 & 169.93450 & 0.00021 & 2539.82700 \\
\hline \multirow{3}{*}{ Inputs } & Labour Expenses $x_{1}$ & 0.31128 & 1.72772 & 0.00026 & 23.85500 \\
\hline & Interest Expenses $\mathrm{x}_{2}$ & 0.20638 & 1.49765 & 0.00005 & 39.77831 \\
\hline & Other Operating Expenses $x_{3}$ & 0.26781 & 1.40532 & 0.00027 & 21.08429 \\
\hline \multirow{3}{*}{ Input Prices } & Price of Labour & 0.01418 & 0.00795 & 0.00013 & 0.20365 \\
\hline & Price of Deposits & 0.01283 & 0.01077 & 0.00001 & 0.06731 \\
\hline & Price of Physical Capital & 0.01094 & 0.02295 & 0.00060 & 0.58604 \\
\hline \multirow{19}{*}{$\begin{array}{c}\text { Concerned } \\
\text { and } \\
\text { Controlled } \\
\text { Variables }\end{array}$} & Commercial Banks & \multicolumn{4}{|c|}{$\begin{array}{c}\text { Dummy Variable, } 1 \text { for commercial, } \\
\text { o for savings banks }\end{array}$} \\
\hline & Unlisted Banks & \multicolumn{4}{|c|}{ Dummy Variable, 1 for unlisted, o for listed banks } \\
\hline & Domestic Banks & \multicolumn{4}{|c|}{$\begin{array}{c}\text { Dummy Variable, } 1 \text { for Domestic, } \\
\text { o for Foreign banks }\end{array}$} \\
\hline & $\mathrm{TC}\left(\mathrm{x}_{1}+\mathrm{x}_{2}+\mathrm{x}_{3}\right)$ & 0.78547 & 4.22927 & 0.00098 & 67.24166 \\
\hline & Total Assets & 25.8079 & 145.9643 & 0.03194 & 2218.9600 \\
\hline & Equity & 2.74263 & 14.73245 & 0.00322 & 214.34300 \\
\hline & Equity to Total Assets \% & 10.9918 & 3.98731 & 4.09100 & 73.63200 \\
\hline & Non-performing loan Ratio \% & 1.43936 & 2.09670 & 0.01600 & 100.00000 \\
\hline & Liquidity $\%$ & 8.01289 & 10.05666 & 0.27600 & 133.57600 \\
\hline & Net Interest Margin \% & 3.86679 & 1.72374 & -0.3440 & 34.93600 \\
\hline & ROAA \% & 1.23548 & 2.00347 & -1.7290 & 76.09700 \\
\hline & Cost-to-Income Ratio \% & 63.5927 & 16.43315 & 9.80400 & 314.57500 \\
\hline & Market Capitalisation & 131.493 & 20.42870 & 78.7800 & 164.84500 \\
\hline & Market Concentration (HHI) & 699.141 & 184.2082 & 451.977 & 949.16640 \\
\hline & Money Supply Growth Rate \% & 5.37858 & 2.91767 & -2.7412 & 11.71349 \\
\hline & GDP Growth Rate \% & 2.10047 & 1.34716 & -2.7755 & 3.78574 \\
\hline & Unemployment \% & 6.10224 & 1.72433 & 3.89560 & 9.63340 \\
\hline & Inflation \% & 2.07943 & 1.05030 & -0.3556 & 3.83910 \\
\hline & Real-Interest Rates \% & 2.32087 & 1.12880 & 1.13733 & 5.24897 \\
\hline
\end{tabular}

\section{Results and Findings}

Tables 2 and 3 shows the detailed average cost and profit efficiency scores of US commercial and savings banks. 
Table 2: Detailed Average Cost Efficiency

\begin{tabular}{|c|c|c|c|c|c|c|c|c|c|c|c|c|}
\hline \multirow[b]{2}{*}{ Period } & \multirow[b]{2}{*}{ Years } & \multirow[b]{2}{*}{ Overall } & \multicolumn{2}{|c|}{ Specialisation } & \multicolumn{4}{|c|}{ Ownership } & \multicolumn{4}{|c|}{ Bank Size } \\
\hline & & & Commercial & Savings & Listed & Unlisted & Foreign & Domestic & $\begin{array}{c}\text { Small } \\
\text { (100bil } \\
\text { or less) }\end{array}$ & $\begin{array}{l}\text { Medium } \\
\text { (101bil- } \\
500 \text { bil) }\end{array}$ & $\begin{array}{c}\text { Large } \\
\text { (501bil- } \\
1500 \text { bil) }\end{array}$ & $\begin{array}{c}\text { Very } \\
\text { large } \\
\text { (1500 bil } \\
\text { or more) }\end{array}$ \\
\hline \multirow{5}{*}{ Pre-crisis } & 2003 & $92.6 \%$ & $93.4 \%$ & $92.6 \%$ & $94.6 \%$ & $93.3 \%$ & $87.1 \%$ & $93.6 \%$ & $93.4 \%$ & $95.4 \%$ & $87.0 \%$ & \\
\hline & 2004 & $93.9 \%$ & $94.0 \%$ & $93.4 \%$ & $93.6 \%$ & $93.9 \%$ & $87.2 \%$ & $94.2 \%$ & $94.0 \%$ & $95.8 \%$ & $87.1 \%$ & \\
\hline & 2005 & $91.5 \%$ & $91.4 \%$ & $93.3 \%$ & $91.6 \%$ & $91.5 \%$ & $82.6 \%$ & $91.8 \%$ & $91.6 \%$ & $90.2 \%$ & $84.2 \%$ & \\
\hline & 2006 & $87.4 \%$ & $87.3 \%$ & $89.4 \%$ & $89.3 \%$ & $87.4 \%$ & $78.5 \%$ & $87.8 \%$ & $87.6 \%$ & $85.5 \%$ & $76.7 \%$ & \\
\hline & Average & $91.4 \%$ & $91.5 \%$ & $92.2 \%$ & $92.3 \%$ & $91.5 \%$ & $83.9 \%$ & $91.8 \%$ & $91.6 \%$ & $91.7 \%$ & $83.8 \%$ & \\
\hline \multirow{4}{*}{ Crisis } & 2007 & $86.5 \%$ & $86.4 \%$ & $87.9 \%$ & $87.6 \%$ & $86.4 \%$ & $81.9 \%$ & $86.6 \%$ & $86.7 \%$ & $82.3 \%$ & $75.2 \%$ & \\
\hline & 2008 & $90.0 \%$ & $90.0 \%$ & $91.5 \%$ & $91.5 \%$ & $90.0 \%$ & $83.3 \%$ & $90.2 \%$ & $90.3 \%$ & $82.6 \%$ & $83.6 \%$ & $78.1 \%$ \\
\hline & 2009 & $91.5 \%$ & $91.5 \%$ & $91.4 \%$ & $92.6 \%$ & $91.4 \%$ & $82.1 \%$ & $91.7 \%$ & $91.5 \%$ & $93.7 \%$ & $91.7 \%$ & $81.7 \%$ \\
\hline & Average & $89.3 \%$ & $89.3 \%$ & $90.3 \%$ & $90.6 \%$ & $89.3 \%$ & $82.4 \%$ & $89.5 \%$ & $89.5 \%$ & $86.2 \%$ & $83.5 \%$ & $79.9 \%$ \\
\hline \multirow{10}{*}{ Post-Crisis } & 2010 & $92.4 \%$ & $92.5 \%$ & $90.1 \%$ & $92.7 \%$ & $92.3 \%$ & $86.8 \%$ & $92.5 \%$ & $92.5 \%$ & $89.7 \%$ & $91.6 \%$ & $82.0 \%$ \\
\hline & 2011 & $92.4 \%$ & $92.3 \%$ & $93.9 \%$ & $91.5 \%$ & $92.5 \%$ & $86.8 \%$ & $92.6 \%$ & $92.5 \%$ & $90.3 \%$ & $93.4 \%$ & $79.4 \%$ \\
\hline & 2012 & $92.9 \%$ & $92.8 \%$ & $93.6 \%$ & $92.7 \%$ & $92.9 \%$ & $91.4 \%$ & $93.0 \%$ & $93.0 \%$ & $91.9 \%$ & $94.4 \%$ & $79.3 \%$ \\
\hline & 2013 & $93.3 \%$ & $93.1 \%$ & $94.5 \%$ & $91.0 \%$ & $93.4 \%$ & $89.9 \%$ & $93.4 \%$ & $93.5 \%$ & $90.2 \%$ & $91.6 \%$ & $75.2 \%$ \\
\hline & 2014 & $93.9 \%$ & $93.8 \%$ & $94.9 \%$ & $92.8 \%$ & $94.0 \%$ & $89.7 \%$ & $94.0 \%$ & $94.2 \%$ & $88.2 \%$ & $90.5 \%$ & $86.0 \%$ \\
\hline & 2015 & $94.3 \%$ & $94.3 \%$ & $94.4 \%$ & $92.8 \%$ & $94.3 \%$ & $93.7 \%$ & $94.3 \%$ & $94.4 \%$ & $91.8 \%$ & $91.2 \%$ & $89.0 \%$ \\
\hline & 2016 & $93.9 \%$ & $93.9 \%$ & $94.1 \%$ & $93.1 \%$ & $93.9 \%$ & $91.6 \%$ & $94.0 \%$ & $94.1 \%$ & $89.4 \%$ & $89.6 \%$ & $88.7 \%$ \\
\hline & 2017 & $94.0 \%$ & $94.1 \%$ & $93.4 \%$ & $93.0 \%$ & $94.0 \%$ & $90.3 \%$ & $94.1 \%$ & $94.2 \%$ & $90.7 \%$ & $90.4 \%$ & $88.0 \%$ \\
\hline & 2018 & $93.8 \%$ & $93.9 \%$ & $93.2 \%$ & $92.5 \%$ & $93.8 \%$ & $89.2 \%$ & $93.9 \%$ & $94.0 \%$ & $90.1 \%$ & $89.7 \%$ & $89.3 \%$ \\
\hline & Average & $93.4 \%$ & $93.4 \%$ & $93.6 \%$ & $92.5 \%$ & $93.5 \%$ & $89.9 \%$ & $93.5 \%$ & $93.6 \%$ & $90.2 \%$ & $91.4 \%$ & $84.1 \%$ \\
\hline \multicolumn{2}{|c|}{ Overall Average } & $92.1 \%$ & $92.2 \%$ & $92.6 \%$ & $92.1 \%$ & $92.2 \%$ & $87.0 \%$ & $92.4 \%$ & $92.3 \%$ & $89.8 \%$ & $88.0 \%$ & $83.3 \%$ \\
\hline
\end{tabular}


Table 3: Detailed Average Profit Efficiency

\begin{tabular}{|c|c|c|c|c|c|c|c|c|c|c|c|c|}
\hline \multirow[b]{2}{*}{ Period } & \multirow[b]{2}{*}{ Years } & \multirow[b]{2}{*}{ Overall } & \multicolumn{2}{|c|}{ Specialisation } & \multicolumn{4}{|c|}{ Ownership } & \multicolumn{4}{|c|}{ Bank Size } \\
\hline & & & Commercial & Savings & Listed & Unlisted & Foreign & Domestic & $\begin{array}{l}\text { Small } \\
\text { (100 bil } \\
\text { or less) }\end{array}$ & $\begin{array}{l}\text { Medium } \\
\text { (101bil- } \\
500 \text { bil) }\end{array}$ & $\begin{array}{l}\text { Large } \\
\text { (501bil- } \\
1500 \text { bil) }\end{array}$ & $\begin{array}{l}\text { Very large } \\
\text { (1500 bil } \\
\text { or more) }\end{array}$ \\
\hline \multirow{5}{*}{ Pre-crisis } & 2003 & $73.1 \%$ & $73.5 \%$ & $64.4 \%$ & $68.9 \%$ & $73.3 \%$ & $70.0 \%$ & $73.2 \%$ & $72.9 \%$ & $88.4 \%$ & $81.0 \%$ & \\
\hline & 2004 & $72.7 \%$ & $73.2 \%$ & $61.0 \%$ & $70.8 \%$ & $72.7 \%$ & $79.3 \%$ & $72.4 \%$ & $72.6 \%$ & $87.1 \%$ & $64.1 \%$ & \\
\hline & 2005 & $70.8 \%$ & $71.1 \%$ & $62.4 \%$ & $70.5 \%$ & $70.8 \%$ & $69.2 \%$ & $70.8 \%$ & $70.7 \%$ & $79.1 \%$ & $64.3 \%$ & \\
\hline & 2006 & $64.4 \%$ & $65.1 \%$ & $48.6 \%$ & $68.4 \%$ & $64.2 \%$ & $61.5 \%$ & $64.5 \%$ & $64.2 \%$ & $73.7 \%$ & $65.0 \%$ & \\
\hline & Average & $70.2 \%$ & $70.7 \%$ & $59.1 \%$ & $69.6 \%$ & $70.2 \%$ & $70.0 \%$ & $70.2 \%$ & $70.1 \%$ & $82.1 \%$ & $68.6 \%$ & \\
\hline \multirow{4}{*}{ Crisis } & 2007 & $53.8 \%$ & $54.5 \%$ & $40.8 \%$ & $48.8 \%$ & $54.0 \%$ & $51.3 \%$ & $53.9 \%$ & $53.8 \%$ & $60.9 \%$ & $34.7 \%$ & \\
\hline & 2008 & $41.9 \%$ & $42.6 \%$ & $26.6 \%$ & $41.9 \%$ & $41.9 \%$ & $42.5 \%$ & $41.9 \%$ & $42.0 \%$ & $42.3 \%$ & $30.0 \%$ & \\
\hline & 2009 & $42.5 \%$ & $43.6 \%$ & $24.2 \%$ & $44.7 \%$ & $42.4 \%$ & $53.6 \%$ & $42.3 \%$ & $43.0 \%$ & $21.4 \%$ & $50.1 \%$ & $27.8 \%$ \\
\hline & Average & $46.1 \%$ & $46.9 \%$ & $30.5 \%$ & $45.2 \%$ & $46.1 \%$ & $49.1 \%$ & $46.0 \%$ & $46.3 \%$ & $41.5 \%$ & $38.3 \%$ & $27.8 \%$ \\
\hline \multirow{10}{*}{ Post-Crisis } & 2010 & $49.9 \%$ & $50.4 \%$ & $42.9 \%$ & $55.6 \%$ & $49.7 \%$ & $50.3 \%$ & $49.9 \%$ & $50.3 \%$ & $40.3 \%$ & $45.0 \%$ & $39.1 \%$ \\
\hline & 2011 & $55.8 \%$ & $56.7 \%$ & $44.2 \%$ & $60.4 \%$ & $55.6 \%$ & $62.1 \%$ & $55.6 \%$ & $56.5 \%$ & $39.6 \%$ & $49.3 \%$ & $42.4 \%$ \\
\hline & 2012 & $62.4 \%$ & $63.7 \%$ & $54.4 \%$ & $61.7 \%$ & $62.5 \%$ & $57.8 \%$ & $62.6 \%$ & $62.7 \%$ & $51.5 \%$ & $63.2 \%$ & $49.2 \%$ \\
\hline & 2013 & $67.0 \%$ & $67.9 \%$ & $61.1 \%$ & $75.6 \%$ & $66.7 \%$ & $69.4 \%$ & $66.9 \%$ & $67.3 \%$ & $50.8 \%$ & $84.0 \%$ & $67.4 \%$ \\
\hline & 2014 & $69.3 \%$ & $70.0 \%$ & $65.1 \%$ & $77.8 \%$ & $69.0 \%$ & $63.4 \%$ & $69.5 \%$ & $69.5 \%$ & $63.2 \%$ & $57.6 \%$ & $79.9 \%$ \\
\hline & 2015 & $68.5 \%$ & $69.2 \%$ & $64.1 \%$ & $68.3 \%$ & $68.5 \%$ & $62.7 \%$ & $68.7 \%$ & $68.8 \%$ & $56.6 \%$ & $82.0 \%$ & $76.7 \%$ \\
\hline & 2016 & $70.8 \%$ & $71.4 \%$ & $67.3 \%$ & $59.8 \%$ & $71.3 \%$ & $62.8 \%$ & $71.1 \%$ & $71.1 \%$ & $62.0 \%$ & $77.7 \%$ & $86.0 \%$ \\
\hline & 2017 & $72.9 \%$ & $73.5 \%$ & $69.4 \%$ & $66.0 \%$ & $73.2 \%$ & $59.0 \%$ & $73.4 \%$ & $73.0 \%$ & $70.5 \%$ & $36.7 \%$ & $86.8 \%$ \\
\hline & 2018 & $81.6 \%$ & $82.5 \%$ & $76.1 \%$ & $71.0 \%$ & $82.0 \%$ & $75.2 \%$ & $81.8 \%$ & $81.6 \%$ & $80.0 \%$ & $34.7 \%$ & $89.8 \%$ \\
\hline & Average & $66.5 \%$ & $67.3 \%$ & $60.5 \%$ & $66.2 \%$ & $66.5 \%$ & $62.5 \%$ & $66.6 \%$ & $66.7 \%$ & $57.2 \%$ & $58.9 \%$ & $68.6 \%$ \\
\hline \multicolumn{2}{|c|}{ Overall Average } & $63.59 \%$ & $64.31 \%$ & $54.54 \%$ & $63.14 \%$ & $63.61 \%$ & $61.88 \%$ & $63.66 \%$ & $63.75 \%$ & $60.46 \%$ & $57.46 \%$ & $64.51 \%$ \\
\hline
\end{tabular}




\subsection{Overall Cost and Profit Efficiency}

Figure 1 on overall average cost and profit efficiency trends shows that cost efficiency of US banks is more stable than their level of profit efficiency especially during the crisis period (red-shaded area).

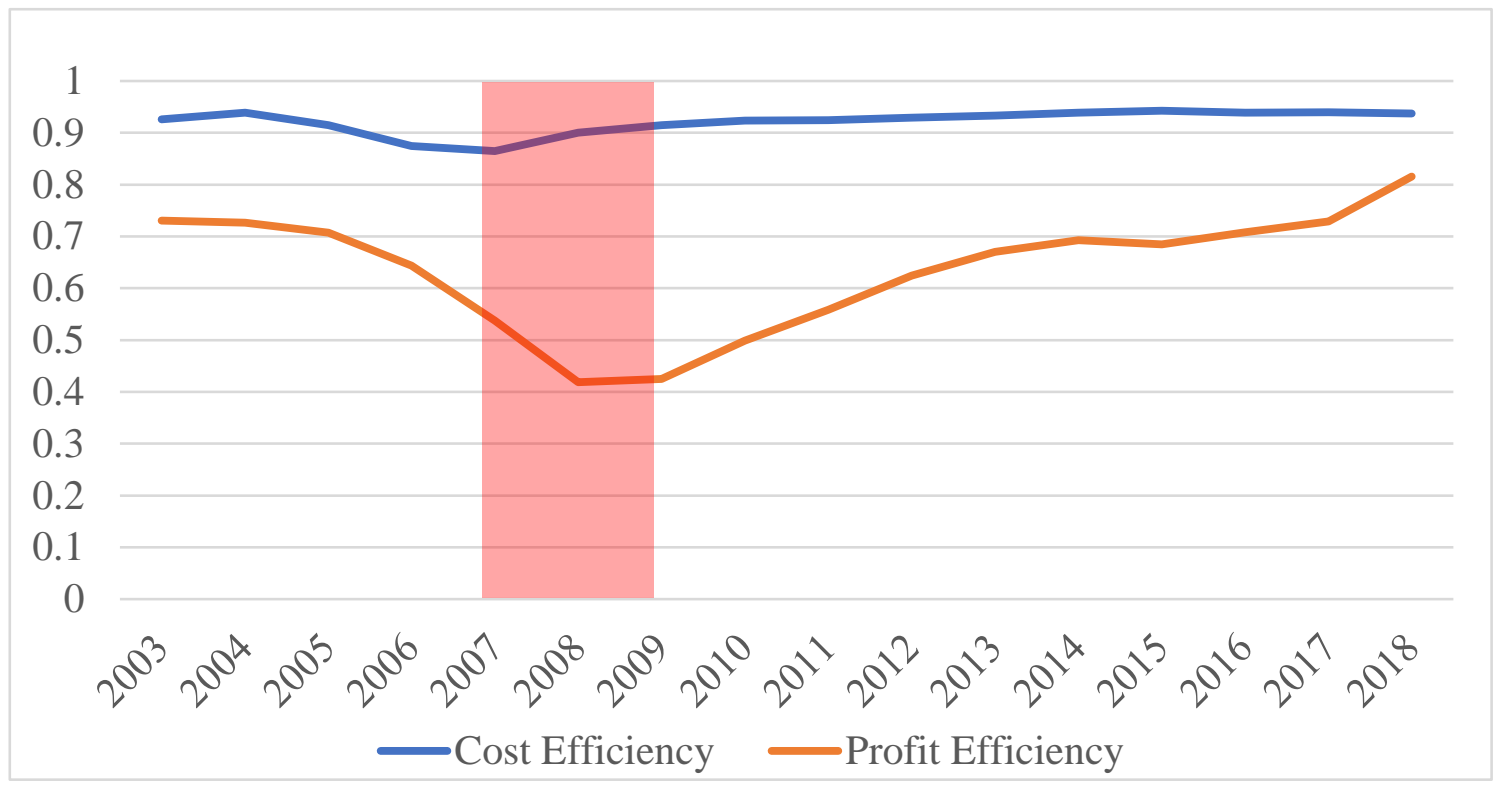

Figure 1: Overall Average Cost and Profit Efficiency

From figure 1 and paired t-test we have found that overall, US commercial banks and savings banks are more cost efficient than the profit efficiency which matches with the results of Berger and Humphrey (1997) and Rogers (1998). The cost efficiency has always been within the range of $86 \%$ to $94.3 \%$ which commensurate with the levels of cost efficiency found in the previous studies (e.g. in Berger and Humphrey, 1997; Bos and Kolari, 2005; Moudos and Pastro, 2003; Fang, et al. 2011; Rogers, 1998). This means that on average US commercial and savings banks are $5.7 \%$ to $14 \%$ inefficient relative to the maximum possible efficiency level. Even though recovered in crisis and post-crisis periods, the cost efficiency had a decreasing trend during the pre-crisis period because of banks' too much involvement in securitisation activities, inconsiderate and extensive lending activities coupled with higher non-performing loans, and the higher remuneration packages for the employees. On the other hand, the profit efficiency was in decreasing trend before and during the GFC and banks had experienced the lowest level of profit efficiency during 2008. Since 2003 banks in the USA are enjoying more than $70 \%$ average profit efficiency meaning banks are on an average $30 \%$ profit inefficient, except during the exceptional years of GFC. These results also do match with the results of previous studies on US banks' profit efficiency (e.g. Berger and Humphrey, 1997; Rogers, 1998; Bos and Kolari, 2005; Moudos and 
Pastro, 2001). As we know that during the GFC the financial sector of the USA, especially the banks were greatly affected, and the profitability and non-performing loans were at their worst. All these caused the profit efficiency of US banks to deteriorate sharply before and during the GFC.

However, since 2010 the improvements in cost and profit efficiency scores are in line with the recovery in the business cycle and improved profitability ratios, noninterest expense ratio, and non-performing loans ratio. Drake and Hall (2003) suggested that banks can minimise the overall cost and profit inefficiencies by minimising operating costs especially the staff expenses. The provision in DoddFrank Act 2010 regarding the revision of remuneration package of executives of banks, is one of the reasons for improvement in bank efficiencies in the USA. Furthermore, the abolishment of the bills passed to provide more mortgages to help consumers to buy more houses, and the careful credit evaluation and distribution also aided to the improvement of overall bank efficiency. Banks have reduced their participation in mortgage lending as non-bank now make up over $80 \%$ of the mortgage market (J.P. Morgan, 2018). The other reasons of the recovery in efficiency scores are the creation of Financial Stability Oversight Council and Consumer Financial Protection Bureau by Federal Reserve, the stricter regulatory reforms included in Doss-Frank Act 2010, Comprehensive Capital Analysis and Review (CCAR) program, and the changes in the capital requirement of BASEL III, implemented by all G-20 countries including USA, which requires that banks having assets of at least $\$ 50$ million will follow stricter operational, capital and liquidity standards.

\subsection{Specialisation and Bank Efficiencies}

This analysis considers both commercial and savings banks of USA. Figure 2 shows that the cost and profit efficiency scores of both commercial and savings banks are very similar and are ranging between $86 \%-95 \%$ whereas, the profit efficiency scores are ranging between $24 \%-82 \%$ with the worst levels during the period of GFC. 


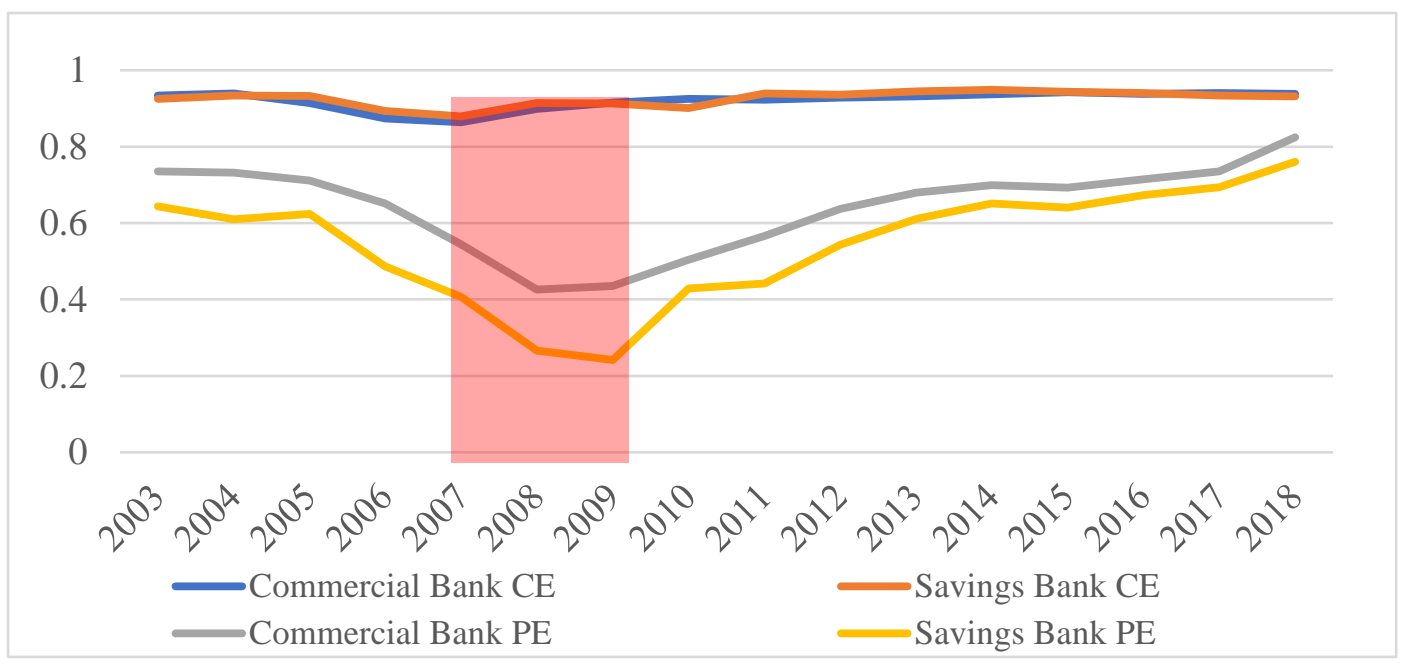

Figure 2: Bank Specialisation and Efficiency

However, a deeper analysis with Kruskal-Wallis test and t-test discovers that savings banks in the USA are more cost efficient than the commercial banks and commercial banks are more profit efficient than savings banks which conforms the results found by Manghetti and Chairman (2011), Lang and Welzel (1996), and Dietsch and Weill (1999). These results confirm the facts that the savings banks are more concerned about the expenses even at the cost of less profitability as they are more involved in retail banking and on the other hand, commercial banks are more concerned about the profitability rather than costs as they are mostly involved in wholesale banking (Mäkinen and Jones, 2015). Alzubaidi and Bougheas (2012) states that commercial banks are less cost efficient because of their lower level of scale efficiency.

\subsection{Private Ownership and Bank Efficiencies}

Moving towards the efficiency of privately owned (not listed on any stock exchange) and publicly owned (listed on a stock exchange) banks, the study found that the cost and profit efficiency of both privately owned and publicly owned banks are similar and the cost and profit efficiency of both types of banks are ranging between $86 \%-95 \%$ and between $41 \%-84 \%$ respectively.

From Figure 3, the effects of GFC on both types of banks are visible from the decreasing and worst cost and profit efficiency levels during the years 2007-2009. 


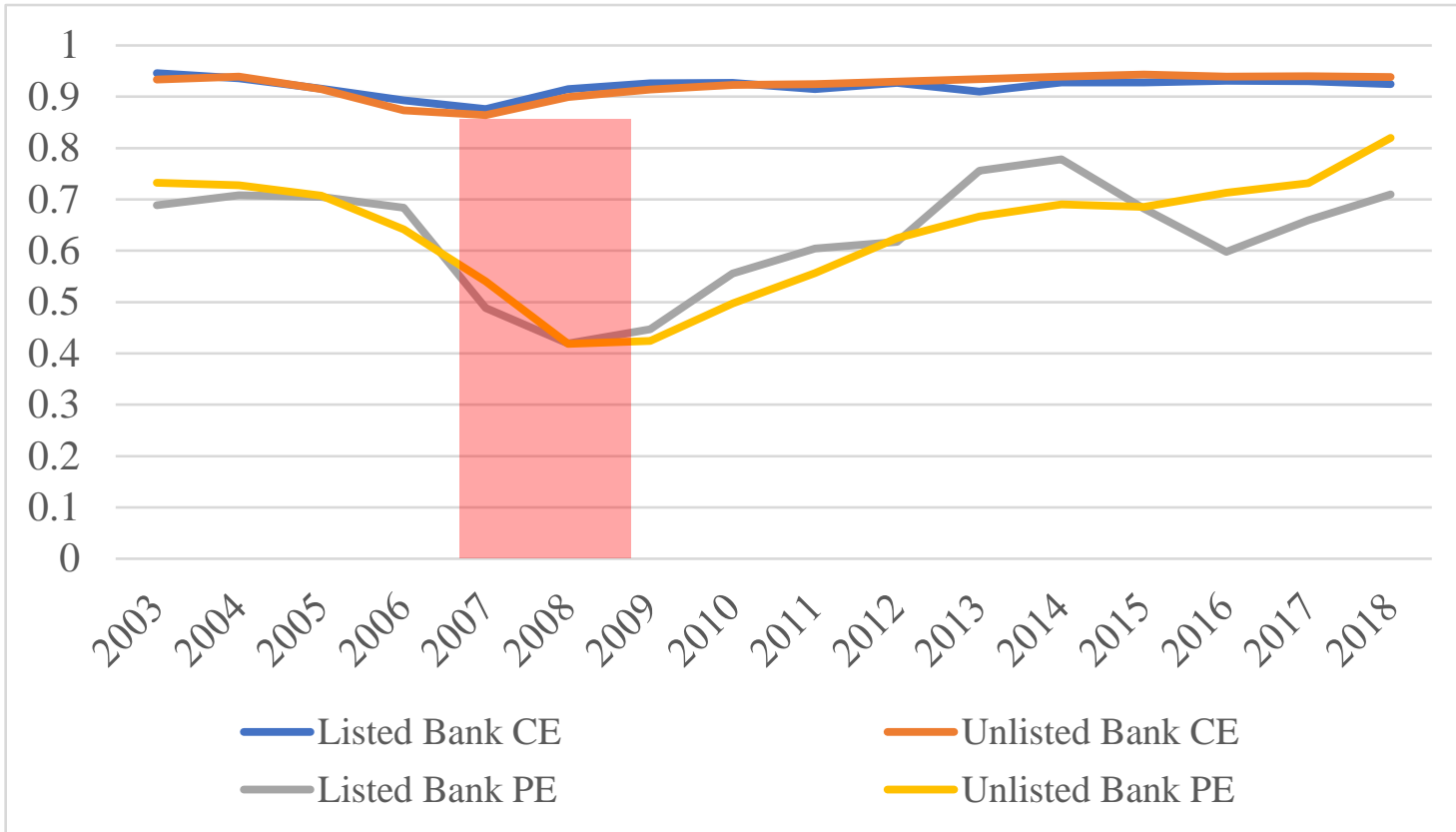

Figure 3: Private Ownership and Bank Efficiency

A closer analysis using t-test and Kruskal-Wallis test also shows that there is no statistically significant difference in the cost and profit efficiencies of privately owned and publicly listed banks in the USA. Weill (2003) and Matousek and Taci (2002) found that privately owned banks are more efficient than the publicly owned banks. However, Frydman et al. (1999) states that if banks are privately owned by its insiders (employees or managers), it does not bring any good to the organization and the performance is better for the banks privately owned by the outsiders. In USA most of the banks are very small and privately owned and there are very few banks which can afford to be listed on the stock exchange. The listed banks tend to be more efficient as they follow certain rules and regulations, specifically the corporate governance practice and face more pressure from the stockholders (Dietrich and Wanzenried, 2011) to operate efficiently. On the other hand, the unlisted banks are smaller in size and cannot afford to be inefficient because of the competition in the industry.

\subsection{Foreign Ownership and Bank Efficiencies}

This analysis also focuses on US banks' ownership structure and efficiency levels. It is found that the cost efficiency levels of both foreign and domestic banks are always between $78 \%$ and $94 \%$. The cost efficiency had slightly decreased during the pre-crisis period but recovered in 2008. On the other side, the profit efficiency of foreign and domestic banks ranges between $42 \%$ and $82 \%$ with a clear mark of worst performance during the GFC. The t-test and Kruskal-Wallis test reveal that foreign banks in the USA are less cost and profit efficient compared to their 
domestic counterparts which contradicts the results of previous studies (e.g. Fries and Taci 2005; Matousek and Taci, 2002; Weill, 2003).

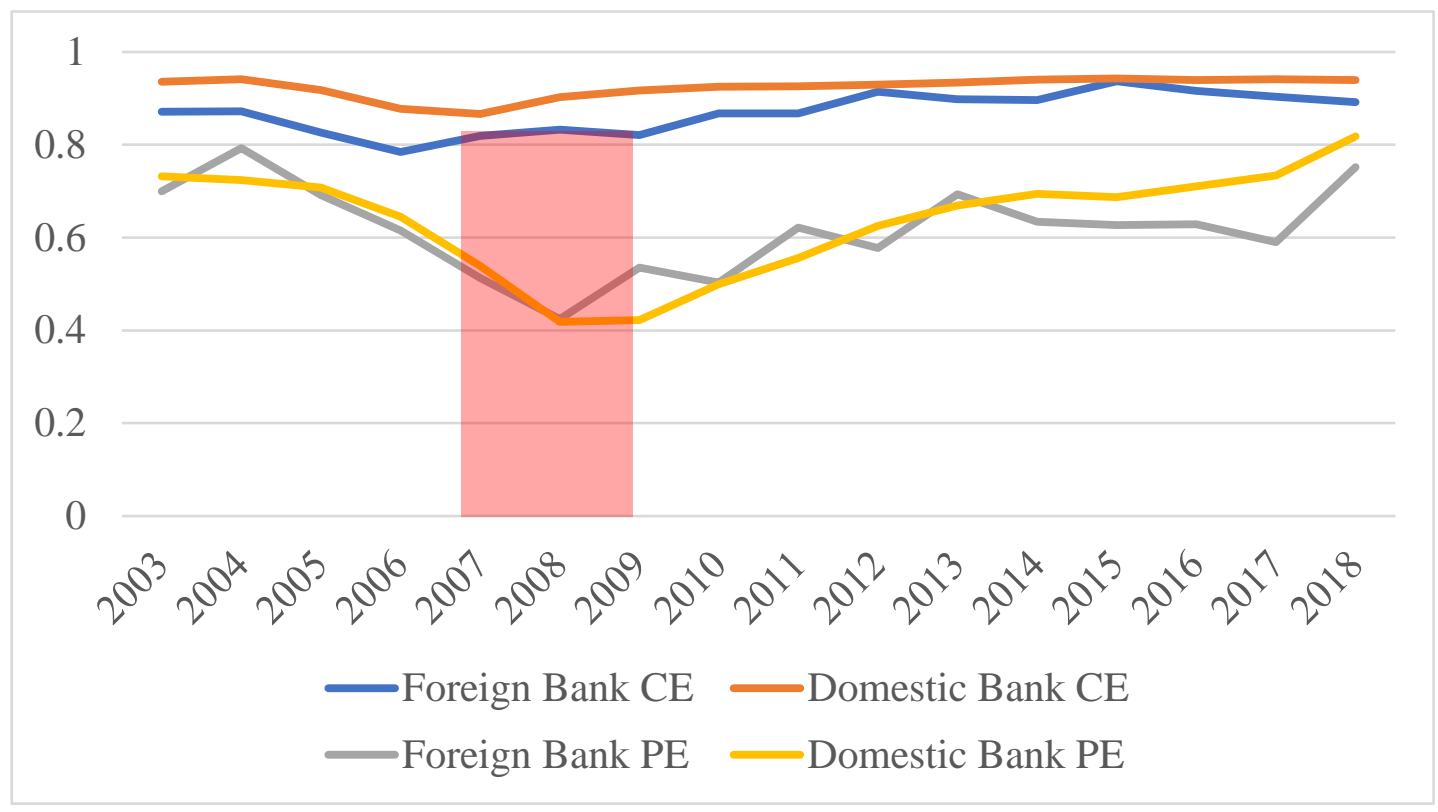

Figure 4: Foreign Ownership and Bank Efficiency

The reasons of foreign banks being less efficient in the USA can be the fact that foreign banks are not freestanding entities, they do not have any capital of their own, and face different regulations and restrictions on accepting deposits than the domestic banks (Federal Reserve Bank of New York, 2007), which limits the business activities of these banks and they become less efficient than the domestic ones. Moreover, foreign banks, if succeed to exploit their comparative advantages into a developed country like the USA, can be more efficient than their domestic counterparts (Havrylchyk, 2006).

\subsection{Bank Size and Efficiencies}

Tables 2 and 3 and Figure 5, shows that banks with varying amount of assets have similar cost efficiency levels. Before, 2008 there were no very large bank in the USA maybe because a lot of banks have been closed down due to the effect of GFC and merger of struggling banks with the other banks which matches with the act of merging the falling banks with stable banks by the regulators as part of their deposit insurance initiative. 


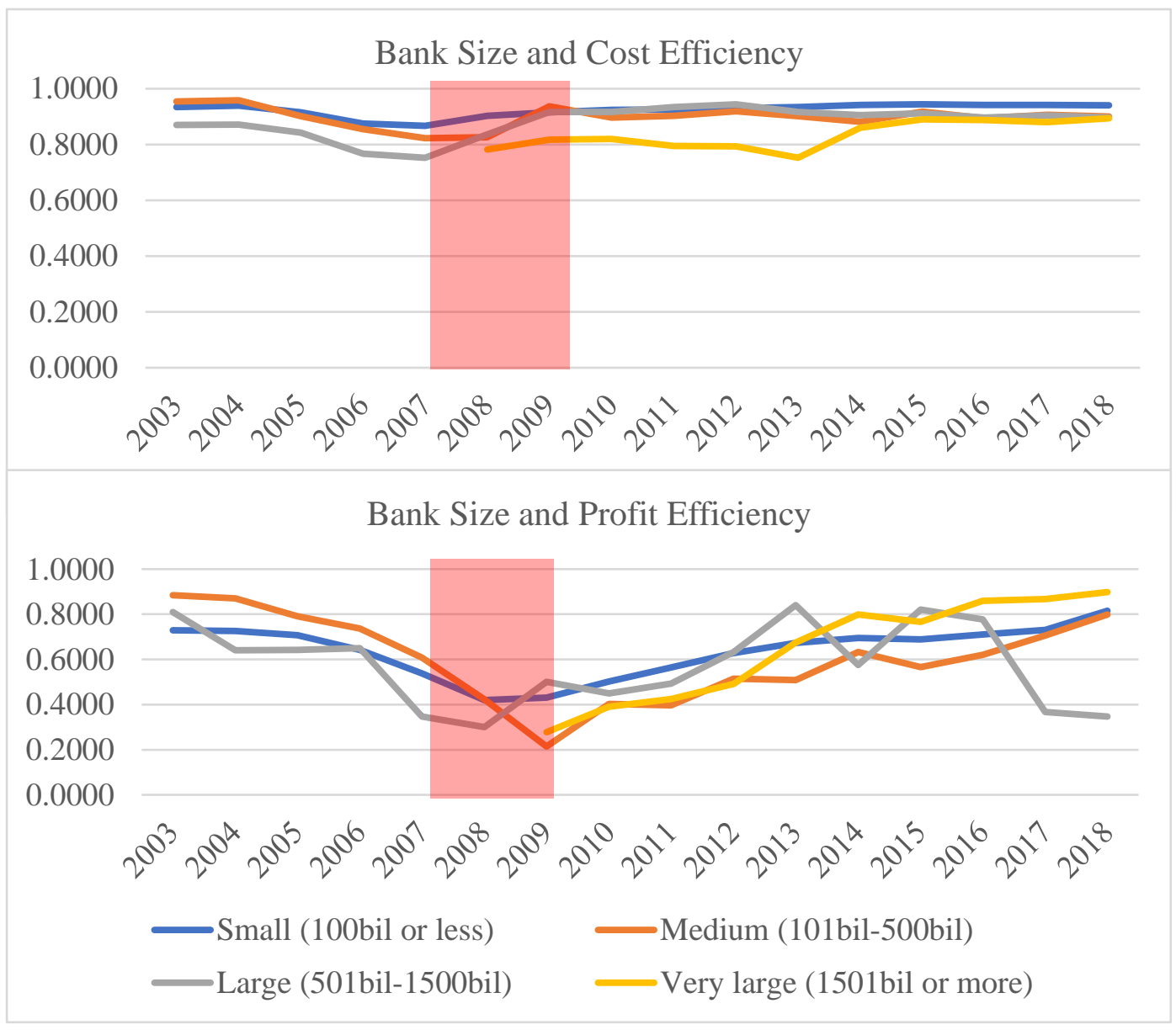

Figure 5: Bank Size and Cost and Profit Efficiency

The cost efficiency levels of these banks ranges from $78 \%$ to $97 \%$ and the profit efficiency level ranges from $21 \%$ to $88 \%$. However, because of the hit of GFC, these banks have experienced the worst levels of cost and profit efficiency during 20072009. The medium, large and very large banks in the USA had the lowest cost and profit efficiency scores during the studied period which reconfirms the results of Berger and Mester (1997) and Akhigbe and McNulty (2003) that smaller banks in the USA are more cost and profit efficient. Because smaller banks- are better able to charge higher rates on loans and to pay lower rates on deposits (Gilbert, 1984; Hannan, 1991), have access to better credit information of the borrowers (Mester, et al. 1998), have lower operating costs and face lower competition than larger banks, they have become more efficient than the larger banks. 


\subsection{Determinants of Cost and Profit Inefficiency}

This study has already presented plenty of analyses that the levels of both cost and profit efficiency are varying across time and different categories of banks. This section focuses on the impact of specialization, ownership structure, and size on the cost and profit efficiencies of US commercial and savings banks along with the impact of other controlled bank-specific, industry-specific, and macroeconomic determinants. Table 5 shows the direction of the impact of different determinants of cost and profit efficiency.

Starting with our concerned variables (specialization, ownership structure, and size), the table shows similar results as discussed in sections 4.1 to 4.5 regarding bank specialization, private and foreign ownership, size and bank efficiencies. Similar to the graphical analysis, the regression results confirm that, US commercial banks are less cost efficient than savings banks but are more profit efficient than the savings banks. As mentioned earlier, the results are similato to the findings of Manghetti and Chairman (2011), Lang and Welzel (1996), and Dietsch and Weill (1999). The reasons are also the same that commercial banks are more engaged with wholesale banking (Mäkinen and Jones, 2015) and less cost concerned than savings banks which are mostly involved in retail banking and much more concern about their costs. O the other hand, unlisted (privately banks) are more (less) cost (profit) efficient than their listed (public) counterparts. These results are again similar to our findings in section 4.2. As the unlisted banks are small in size and their scope of doing business is smaller hence remain very concerned about their costs (Dietrich and Wanzenried, 2011). Whereas, the listed banks are bigger in size with the capital raised from the financial market floating securities, have more scope of doing business, hence become less concern about cost but not profit. Moving towards the domestic ownership variable, the analysis also found that domestic banks in USA are more cost and profit efficient than their foreign counterparts. These results are contradictory to the results of Fries and Taci (2005); Matousek and Taci (2002); and Weill (2003). The reasons are also similar as discussed previously that the foreign banks in USA may not be able exploit their competitive advantage in developed countries than in developing countries; and that they face different regulatory restrictions in accepting deposits in USA (Federal Reserve Bank of New York, 2007). Finally, the results regarding our last concerned variable, size, show that there is a significant positive relation between bank size and the level of cost and profit inefficiencies, which means that with the increase in size the efficiency of banks decreases. The result is similar to the graphical presentation in section 4.5 but contradicts with the results found in studies (e.g. Yildirim and Philippatos, 2007; Tecles and Tabak, 2010; Ariff and Can, 2008; Cole and Gunther, 1995) not involving USA. However, there are studies (e.g. Akhigbe and McNulty, 2001; Isik and Hasan, 2002) that found that in USA, smaller banks are more efficient than the larger banks. The reasons are same as stated earlier that smaller banks- are better able to charge higher rates on loans and to pay lower rates on deposits (Gilbert, 1984; Hannan, 1991), they have easy access to better credit information of the 
borrowers (Mester, et al. 1998), and have lower operating costs and face lower competition than larger banks.

Table 5: Determinants of Cost and Profit Inefficiency

\begin{tabular}{|c|c|c|c|}
\hline \multirow{2}{*}{ Categories of Determinants } & \multirow{2}{*}{ Determinants } & \multicolumn{2}{|c|}{$\begin{array}{l}\text { From Battese and Coelli } 1995 \\
\text { Inefficiency effects model }\end{array}$} \\
\hline & & $\begin{array}{c}\text { Cost } \\
\text { Inefficiency }\end{array}$ & $\begin{array}{c}\text { Profit } \\
\text { Inefficiency }\end{array}$ \\
\hline \multirow{4}{*}{ 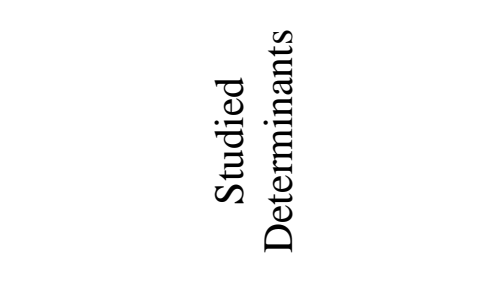 } & Commercial Banks & $0.06337 * * *$ & $-0.0300^{*}$ \\
\hline & Unlisted Banks & -0.0221 & 0.0275 \\
\hline & Domestic Banks & $-0.0750 * * *$ & -0.0334 \\
\hline & Size & $0.0124 * * *$ & $0.0193^{*}$ \\
\hline \multirow{10}{*}{ 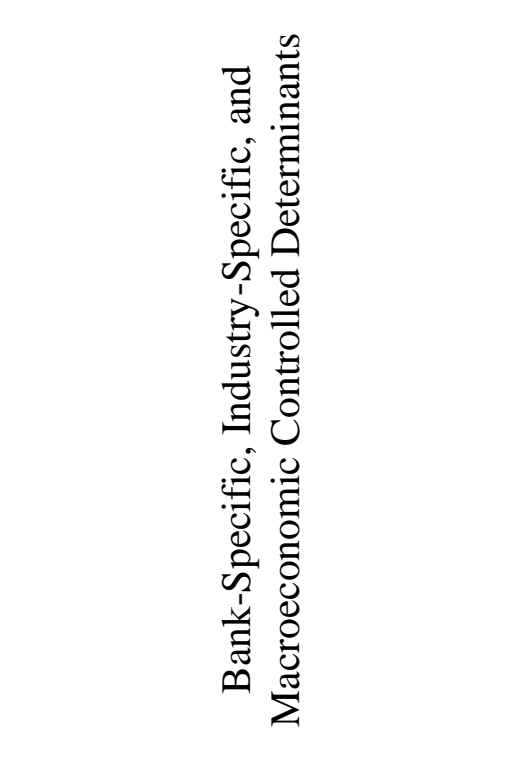 } & Liquidity & $0.0123^{* * *}$ & -0.0010 \\
\hline & $\begin{array}{c}\text { Expense } \\
\text { Management }\end{array}$ & $0.0056^{* * *}$ & $0.0157 * * *$ \\
\hline & Asset Quality & 0.0048 & $0.0761 * * *$ \\
\hline & Capitalisation & $-0.0163 * * *$ & $0.0237 * * *$ \\
\hline & $\begin{array}{c}\text { Market } \\
\text { Concentration }\end{array}$ & -0.00007 & $-1.4359 * * *$ \\
\hline & Economic Growth & -0.0011 & $-0.00112 * * *$ \\
\hline & Unemployment & $0.0326 * * *$ & 0.0101 \\
\hline & Inflation & $0.0304 * * *$ & 0.0119 \\
\hline & Money Supply & $0.0086^{* * *}$ & 0.0017 \\
\hline & Interest Rates & $0.0837 * * *$ & $-0.0947 * * *$ \\
\hline
\end{tabular}

$*=$ Significant at $10 \% * *=$ Significant at $5 \% * * *=$ Significant at $1 \%$

Moving forward to the bank-specific characteristics, the results reveal that liquidity level of the banks is significantly positively influencing cost inefficiency meaning higher liquidity reduces cost efficiency which is expected because the higher liquidity means more idle funds and less lending (Sufian, 2009). Again, liquidity level is negatively influencing profit inefficiency which means with the higher level of liquidity the profit inefficiency decreases. The reason can be reduction of liquidity risk of the banks leading to obtain funds at a cheaper cost. Further, expense management or cost-to-income ratio is very significantly positively influencing both cost and profit inefficiencies. This means that more expense leads to lesser cost and profit efficiencies. The result is consistent with the bad management hypothesis 
of Berger and DeYoung (1997). The lower efficiency can be the result of poor control of operating expenses, poor senior management practice of managing inputs, and inadequate underwriting, controlling, and monitoring of loans (Sufian, 2009).

Another very important bank-specific determinant, asset quality measured by the level of impaired loans to total loans ratio, is positively correlated with the cost and profit inefficiencies and the impact is very significant on the profit inefficiency. The result is consistent with the existing studies (e.g. Altunbas, et al. 200; Sufian, 2009; Yildirim and Philippatos, 2007) and with our previous findings that the US banks have experienced a huge loss due to the burden of defaulted loans during GFC which caused a reduction in the efficiency levels. We have already observed that the recovery in efficiency since 2010 couples with the recovery of non-performing loans ratios of US banks. Therefore, banks in the USA should always be very concerned about the quality of their loan portfolios and loan underwriting, monitoring, and controlling process. On the other side, Capitalisation, measured as total equity to total asset ratio, is very significantly affecting cost inefficiency negatively, and profit inefficiency positively. These results are similar to the results found by Yildirim and Philippatos (2007), Pasiouras et al. (2009), and Berger and Mester (1997), that well-capitalised banks are more cost efficient. According to $\mathrm{Vu}$ and Nahm (2013) the reason is that well-capitalised banks, being safer, try to aggressively take risk and distribute more loans. Havrylchyk (2005) claims that well-capitalised banks can borrow at lower cost from the market which increases cost efficiency. Besides, a higher capital reduces profit efficiency of the banks in the USA as found by Cavallo and Rossi (2002), and Pariouras et al. (2009). Vu and Nahm (2013) states that the act of taking aggressively higher risk and keeping capitalisation to lower level, help banks to increase profit efficiency.

Moving towards the external factors, the analysis found that the level of market concentration (measured with HHI) of the banking industry in USA influences cost and profit inefficiencies negatively. The result is significant for profit inefficiency and consistent with the studies (e.g. Mesa, et al. 2014; Pasiouras, et al. 2009; Kosak, et al. 2006; and Akhigbe and McNulty, 2001) which suggest that higher concentration provides monopolistic power, decreases the competition in the market and helps earning more revenues and making more loans, hence increases efficiency (Yu and Neus, 2005). Expectedly, economic growth, measured by the growth rate of real GDP, is negatively correlated to cost inefficiency and very significantly negatively with profit inefficiency as found by Pasiouras et al. (2009), Yildirim and Philipattos (2007), and Hermes and Nhung (2007). These studies suggest that during the expansion period, the demand for bank loans increases and so do the income from those loans and both cost and profit efficiency, because of the increase in the outputs and profit.

On the other hand, inflation and unemployment are positively influencing cost and profit inefficiency. This result is also consistent with the literature and $\mathrm{Vu}$ and $\mathrm{Nahm}$ (2005) states that unstable inflation creates macroeconomic and financial instability and banks face difficulty to maximize their efficiency because of the increased 
operating costs and uncertain and distorted relative input prices. Similarly, the money supply is significantly positively correlated to cost inefficiency and insignificantly positively to profit inefficiency because the increased money supply decreases the demand for loans and reduces profitability and efficiency. In contrast, the interest rate found to be significantly influencing both cost and profit inefficiencies which supports the notion that increased interest rate raises the cost of funds and lowers the demand for a loan. This ultimately increases the cost inefficiency. Whereas, the relationship between the interest rate and profit inefficiency is negative and supports the theory that increased interest rates increases interest income and enhance profit efficiency at the same level of inputs used.

\section{Conclusion and Scope for Further Research}

To sum up, the efficiency results indicate that overall cost efficiency of US commercial and savings banks found to be higher than the profit efficiency. The overall average cost efficiency is $92.1 \%$ and during the crisis period, the cost efficiency was lowest $(89.3 \%$ ) which means the cost efficiency was not much affected by GFC. During all the three periods, the average cost efficiency is the lowest for the very large banks and ranged between $79 \%$ to $83.3 \%$. On the other hand, the overall average profit efficiency is estimated as $63.59 \%$ and the profit efficiency of every type of banks was badly affected by GFC when the overall average was only $46.1 \%$ compared to the $70.2 \%$ during the pre-crisis period and $66.5 \%$ during the post-crisis period. Among the different categories of banks, the savings banks' average profit efficiency level was the worst in every period with $54.54 \%, 59.1 \%, 30.5 \%$, and $60.5 \%$ overall, during pre-crisis, crisis, and post-crisis periods respectively. Moreover, it is found that savings banks in the USA are more cost efficient than the commercial banks and commercial banks are more profit efficient than savings banks which is a normal case; there are no significant differences between the cost and profit efficiencies of listed and unlisted banks; and foreign banks are less cost and profit efficient compared to their domestic counterparts which is not a usual case. Finally, the medium, large and very large banks considered in this study have experienced the lowest cost and profit efficiency scores during the studied period. The analysis of the determinants of cost and profit efficiency shows that, bank size, liquidity, expense management, capitalisation unemployment, inflation, money supply, and interest rates are significantly influencing the level of cost efficiency of banks under consideration. Further, expense management, asset quality, capitalisation, market concentration, economic growth, and prevailing interest rates are found to be significantly affecting profit efficiency.

As a continuation, this study can also be extended involving multiple developed countries like Japan, Germany, France and others alongside USA for an international comparison. The consideration of state-level differences in banks' production technology and incorporation of regulatory variables to investigate the 
impact of regulations on banks' cost and profit efficiencies in USA can be a topic of interest for further research with this recent dataset.

\section{References}

[1] Akhigbe, A. and McNulty, J., (2005). Profit efficiency sources and differences among small and large US commercial banks. Journal of Economics and Finance, 29(3), pp.289-299.

[2] Al-Sharkas, A.A., Hassan, M.K. and Lawrence, S., (2008). The impact of mergers and acquisitions on the efficiency of the US banking industry: further evidence. Journal of Business Finance \& Accounting, 35(1-2), pp.50-70.

[3] Altunbas, Y., Evans, L. and Molyneux, P., (2001). Bank ownership and efficiency. Journal of money, credit and banking, pp.926-954.

[4] Alzubaidi, H. and Bougheas, S., (2012). The impact of the global financial crisis on European Banking Efficiency (No. 12/05).

[5] Ariff, M. and Luc, C., (2008). Cost and profit efficiency of Chinese banks: A non-parametric analysis. China Economic Review, 19(2), pp.260-273.

[6] Banya, R. and Biekpe, N., (2018). Banking Efficiency and its determinants in selected Frontier African Markets. Economic Change and Restructuring, 51(1), pp.69-95.

[7] Battese, G.E. and Coelli, T.J., (1988). Prediction of firm-level technical efficiencies with a generalized frontier production function and panel data. Journal of econometrics, 38(3), pp.387-399.

[8] Battese, G.E. and Coelli, T.J., (1995). A model for technical inefficiency effects in a stochastic frontier production function for panel data. Empirical economics, 20(2), pp.325-332.

[9] Battese, G.E. and Corra, G.S., (1977). Estimation of a production frontier model: with application to the pastoral zone of Eastern Australia. Australian journal of agricultural economics, 21(3), pp.169-179.

[10] Bauer, P.W., Berger, A.N. and Humphrey, D.B., (1993). Efficiency and productivity growth in US banking. The measurement of productive efficiency: Techniques and applications, pp.386-413.

[11] Bauer, P.W., Berger, A.N., Ferrier, G.D. and Humphrey, D.B., (1998). Consistency conditions for regulatory analysis of financial institutions: a comparison of frontier efficiency methods. Journal of Economics and business, 50(2), pp.85-114.

[12] Benston, G.J., (1965). Branch banking and economies of scale. The Journal of Finance, 20(2), pp.312-331.

[13] Berger, A.N. and Humphrey, D.B., (1991). The dominance of inefficiencies over scale and product mix economies in banking. Journal of Monetary Economics, 28(1), pp.117-148.

[14] Berger, A.N. and Humphrey, D.B., (1997). Efficiency of financial institutions: International survey and directions for future research. European journal of operational research, 98(2), pp.175-212. 
[15] Berger, A.N. and Mester, L.J., (1997). Inside the black box: What explains differences in the efficiencies of financial institutions?. Journal of banking \& finance, 21(7), pp.895-947.

[16] Berger, A.N., Hanweck, G.A. and Humphrey, D.B., (1987). Competitive viability in banking: Scale, scope, and product mix economies. Journal of monetary economics, 20(3), pp.501-520.

[17] Berger, A.N., Hunter, W.C. and Timme, S.G., (1993). The efficiency of financial institutions: A review and preview of research past, present and future. Journal of Banking \& Finance, 17(2-3), pp.221-249.

[18] Bhatia, V., Basu, S., Mitra, S.K. and Dash, P., (2018). A review of bank efficiency and productivity. OPSEARCH, 55(3-4), pp.557-600.

[19] Bos, J.W. and Kolari, J.W., (2005). Large bank efficiency in Europe and the United States: are there economic motivations for geographic expansion in financial services?. the Journal of Business, 78(4), pp.1555-1592.

[20] Carvallo, O. and Kasman, A., (2005). Cost efficiency in the Latin American and Caribbean banking systems. Journal of international financial Markets, Institutions and Money, 15(1), pp.55-72.

[21] Cavallo, L. and Rossi, S.P., (2002). Do environmental variables affect the performance and technical efficiency of the European banking systems? A parametric analysis using the stochastic frontier approach. The European Journal of Finance, 8(1), pp.123-146.

[22] Clark, J.A. and Siems, T.F., (2002). X-efficiency in banking: Looking beyond the balance sheet. Journal of Money, Credit and Banking, pp.987-1013.

[23] Coelli, T. and Perelman, S., (1999). A comparison of parametric and nonparametric distance functions: With application to European railways. European journal of operational research, 117(2), pp.326-339.

[24] Coelli, T., Estache, A., Perelman, S. and Trujillo, L., (2003). A primer on efficiency measurement for utilities and transport regulators. The World Bank.

[25] Coelli, T.J., Rao, D.S.P., O'Donnell, C.J. and Battese, G.E., (2005). An introduction to efficiency and productivity analysis. Springer Science \& Business Media.

[26] Cole, R.A. and Gunther, J.W., (1995). Separating the likelihood and timing of bank failure. Journal of Banking \& Finance, 19(6), pp.1073-1089.

[27] Corrigan, E.G., (1982). Are banks special?. Minneapolis, MN: Federal Reserve Bank of Minneapolis.

[28] Das, A. and Ghosh, S., (2009). Financial deregulation and profit efficiency: A nonparametric analysis of Indian banks. Journal of Economics and Business, 61(6), pp.509-528.

[29] Delis, M.D., Koutsomanoli-Fillipaki, A., Staikouras, C.K. and Katerina, G., (2009). Evaluating cost and profit efficiency: a comparison of parametric and nonparametric methodologies. Applied Financial Economics, 19(3), pp.191202. 
[30] Dell'Atti, S., Pacelli, V. and Mazzarelli, G., (2015). The efficiency of the European banking groups and its determinants. Managerial Finance, 41(7), pp.734-751.

[31] DeYoung, R. and Hasan, I., (1998). The performance of de novo commercial banks: A profit efficiency approach. Journal of Banking \& Finance, 22(5), pp.565-587.

[32] Dietrich, A. and Wanzenried, G., (2011). Determinants of bank profitability before and during the crisis: Evidence from Switzerland. Journal of International Financial Markets, Institutions and Money, 21(3), pp.307-327.

[33] Dietsch, M. and Weill, L., (1999). Les performances des banques de dépôts françaises: une évaluation par la méthode DEA. La méthode DEA, pp.1-16.

[34] Drake, L. and Hall, M.J., (2003). Efficiency in Japanese banking: An empirical analysis. Journal of Banking \& Finance, 27(5), pp.891-917.

[35] Elyasiani, E. and Mehdian, S., (1990). Efficiency in the commercial banking industry, a production frontier approach. Applied Economics, 22(4), pp.539551.

[36] Elyasiani, E. and Mehdian, S.M., (1990). A nonparametric approach to measurement of efficiency and technological change: The case of large US commercial banks. Journal of Financial Services Research, 4(2), pp.157-168.

[37] Fan, L. and Shaffer, S., (2004). Efficiency versus risk in large domestic US banks. Managerial Finance, 30(9), pp.1-19.

[38] Fang, Y., Hasan, I. and Marton, K., (2011). Bank efficiency in South-Eastern Europe. Economics of Transition, 19(3), pp.495-520.

[39] Federal Reserve Bank of New York, (2007), International banking Facilities, https://www.newyorkfed.org/aboutthefed/fedpoint/fed34.html

[40] Ferrier, G.D. and Lovell, C.K., (1990). Measuring cost efficiency in banking: Econometric and linear programming evidence. Journal of econometrics, 46(12), pp.229-245.

[41] Fries, S. and Taci, A., (2005). Cost efficiency of banks in transition: Evidence from 289 banks in 15 post-communist countries. Journal of Banking \& Finance, 29(1), pp.55-81.

[42] Frydman, R., Hessel, M. and Rapaczynski, A., (1998). Why ownership matters?: Politicization and entrepreneurship in the restructuring of enterprises in Central Europe (Vol. 14). New York University, Faculty of Arts and Science, Department of Economics.

[43] Gardener, E., Molyneux, P. and Nguyen-Linh, H., (2011). Determinants of efficiency in South East Asian banking. The Service Industries Journal, 31(16), pp.2693-2719.

[44] Gilbert, R.A., (1984). Bank market structure and competition: a survey. Journal of Money, Credit and Banking, 16(4), pp.617-645.

[45] Hannan, T.H., (1991). Bank commercial loan markets and the role of market structure: Evidence from surveys of commercial lending. Journal of Banking \& Finance, 15(1), pp.133-149. 
[46] Havrylchyk, O., (2006). Efficiency of the Polish banking industry: Foreign versus domestic banks. Journal of Banking \& Finance, 30(7), pp.1975-1996.

[47] Hermes, N. and Nhung, V.T.H., (2010). The impact of financial liberalization on bank efficiency: evidence from Latin America and Asia. Applied Economics, 42(26), pp.3351-3365.

[48] Hughes, J.P. and Mester, L.J., (2013). Who said large banks don't experience scale economies? Evidence from a risk-return-driven cost function. Journal of Financial Intermediation, 22(4), pp.559-585.

[49] Isik, I. and Hassan, M.K., (2002). Cost and profit efficiency of the Turkish banking industry: An empirical investigation. Financial Review, 37(2), pp.257-279.

[50] Jondrow, J., Lovell, C.K., Materov, I.S. and Schmidt, P., (1982). On the estimation of technical inefficiency in the stochastic frontier production function model. Journal of econometrics, 19(2-3), pp.233-238.

[51] Kasman, A. and Yildirim, C., (2006). Cost and profit efficiencies in transition banking: the case of new EU members. Applied Economics, 38(9), pp.10791090.

[52] Kirkpatrick, C., Murinde, V. and Tefula, M., (2008). The measurement and determinants of $\mathrm{x}$-inefficiency in commercial banks in Sub-Saharan Africa. The European Journal of Finance, 14(7), pp.625-639.

[53] Kmenta, J., (1967). On estimation of the CES production function. International Economic Review, 8(2) pp. 180-189

[54] Košak, M., Zajc, P. and Zorić, J., (2009). Bank efficiency differences in the new EU member states. Baltic Journal of Economics, 9(2), pp.67-89.

[55] Laeven, L., (1999). Risk and efficiency in East Asian banks. The World Bank., December.

[56] Lang, G. and Welzel, P., 1996. Efficiency and technical progress in banking Empirical results for a panel of German cooperative banks. Journal of Banking \& Finance, 20(6), pp.1003-1023.

[57] Levine, R., (1998). The legal environment, banks, and long-run economic growth. Journal of money, credit and banking, pp.596-613.

[58] Lozano-Vivas, A. and Pasiouras, F., (2010). The impact of non-traditional activities on the estimation of bank efficiency: international evidence. Journal of Banking \& Finance, 34(7), pp.1436-1449.

[59] Mäkinen, M. and Jones, D.C., (2015). Comparative efficiency between cooperative, savings and commercial banks in Europe using the frontier approach. Annals of Public and Cooperative Economics, 86(3), pp.401-420.

[60] Manghetti, G. and Chairman, C.D.R.D.V.I., (2011). Do savings banks differ from traditional commercial banks?.

[61] Matoušek, R. and Taci, A., (2002). Banking efficiency in transition economies: Empirical evidence from the Czech Republic (No. 02-3). Discussion Paper.

[62] Matthews, K. and Zhang, N.X., (2010). Bank productivity in China 1997-2007: measurement and convergence. China Economic Review, 21(4), pp.617-628. 
[63] Maudos, J. and Pastor, J. M. (2003), "Cost and profit efficiency in the Spanish banking sector (1985-1996): A non-parametric approach," Applied Financial Economics 13(1): 1-12.

[64] Maudos, J., Pastor, J.M., Perez, F. and Quesada, J., (2002). Cost and profit efficiency in European banks. Journal of international financial markets, institutions and money, 12(1), pp.33-58.

[65] Mesa, R.B., Sánchez, H.M. and Sobrino, J.N.R., (2014). Main determinants of efficiency and implications on banking concentration in the European Union. Revista de Contabilidad, 17(1), pp.78-87.

[66] Mester, L.J., Nakamura, L.I. and Renault, M., (1998). Checking accounts and bank monitoring, Federal Reserve Bank of Philadelphia (No. 98-25). Working paper.

[67] Miller, S.M. and Noulas, A.G., (1996). The technical efficiency of large bank production. Journal of Banking \& Finance, 20(3), pp.495-509.

[68] Muazaroh, Eduardus, T., Husnan, S. and Hanafi, M.M., (2012). Determinants of bank profit efficiency: Evidence from Indonesia. International Journal of Economics and Finance Studies, 4(2), pp.163-173.

[69] Pasiouras, F., Delis, M.D. and Papanikolaou, N.I., (2009). Determinants of bank efficiency: evidence from a semi-parametric methodology. Managerial finance.

[70] Pasiouras, F., Tanna, S. and Zopounidis, C., (2009). The impact of banking regulations on banks' cost and profit efficiency: Cross-country evidence. International Review of Financial Analysis, 18(5), pp.294-302.

[71] Restrepo-Tobón, D.A. and Kumbhakar, S.C., (2017). A new method to decompose profit efficiency: an application to US commercial banks. Journal of Productivity Analysis, 48(2-3), pp.117-132.

[72] Rogers, K.E., (1998). Nontraditional activities and the efficiency of US commercial banks. Journal of Banking \& Finance, 22(4), pp.467-482.

[73] Rouissi, R.B., (2011). Cost and profit efficiency of French commercial banks. Munich Personal RePEc Archive.

[74] Schumpeter, J.A. and Opie, R., (1961). The theory of economic development: an inquiry into profits, capital, credit, interest, and the business cycle. Cambridge, MA: Harvard University Press.

[75] Sealey Jr, C.W. and Lindley, J.T., (1977). Inputs, outputs, and a theory of production and cost at depository financial institutions. The journal of finance, 32(4), pp.1251-1266.

[76] Semih Yildirim, H. and Philippatos, G.C., (2007). Efficiency of banks: Recent evidence from the transition economies of Europe, 1993-2000. European Journal of Finance, 13(2), pp.123-143.

[77] Sufian, F., (2009). Determinants of bank efficiency during unstable macroeconomic environment: Empirical evidence from Malaysia. Research in International Business and Finance, 23(1), pp.54-77. 
[78] Tecles, P.L. and Tabak, B.M., (2010). Determinants of bank efficiency: The case of Brazil. European Journal of Operational Research, 207(3), pp.15871598.

[79] Tsionas, E.G., Malikov, E. and Kumbhakar, S.C., (2018). An internally consistent approach to the estimation of market power and cost efficiency with an application to US banking. European Journal of Operational Research, 270(2), pp.747-760.

[80] Vennet, R.V., (2002). Cost and profit efficiency of financial conglomerates and universal banks in Europe. Journal of Money, Credit and Banking, pp.254282.

[81] Vu, H. and Nahm, D., (2013). The determinants of profit efficiency of banks in Vietnam. Journal of the Asia Pacific Economy, 18(4), pp.615-631.

[82] Wang, H.J. and Schmidt, P., (2002). One-step and two-step estimation of the effects of exogenous variables on technical efficiency levels. journal of Productivity Analysis, 18(2), pp.129-144.

[83] Webb, R., (2003). Levels of efficiency in UK retail banks: a DEA window analysis. Int. J. of the economics of business, 10(3), pp.305-322.

[84] Weill, L., (2003). Banking efficiency in transition economies: The role of foreign ownership. Economics of transition, 11(3), pp.569-592.

[85] Yu, P. and Neus, W., (2005). Market structure, scale efficiency, and risk as determinants of German banking profitability, Tuebinger

Diskussionsbeitreage, No. 294. 